Saudi Journal of Business and Management Studies Abbreviated Key Title: Saudi J Bus Manag Stud ISSN 2415-6663 (Print) |ISSN 2415-6671 (Online) Scholars Middle East Publishers, Dubai, United Arab Emirates Journal homepage: https://saudijournals.com/sjbms

Review Article

\title{
Cross-Border Shopping on Consumer Satisfaction Survey-The Case of COVID-19 was analyzed
}

\author{
Li-Wei Lin ${ }^{1 *}$, Su-Rong Yan ${ }^{1}$, Jia-Lu Zhou ${ }^{1}$, Rajesh Kaluri ${ }^{2}$ \\ ${ }^{1-3}$ School of Information, Zhejiang University of Finance and Economics Dongfang College, Zhejiang, China \\ ${ }^{4}$ Department of Software and Systems Engineering, VIT University, Vellore Tamil Nadu, India
}

\author{
DOI: $10.36348 /$ sjbms.2020.v05i03.003
}

| Received: 03.03.2020 | Accepted: 10.03.2020 | Published: 13.03.2020

*Corresponding author: Li-Wei Lin

\section{Abstract}

Cross-border shopping represents an important concept for online cross-border e-commerce in 2020. We took place in mainland China with the covid-19 in 2019, which led to a large number of consumers buying masks globally. Many consumers will go to other countries to buy medical products such as masks and alcohol through online cross-border means. Consumers' purchase cognition, impulse purchase and illness information all lead to consumers' purchase intention and satisfaction. The public medical event caused consumers to buy masks, alcohol and other medical products in large quantities to prevent the epidemic. The results of this study show that consumers' expected purchase of goods, mainly due to the shortage of masks, indirectly leads to consumers' expected purchase of goods on online foreign ecommerce platforms. We found that consumers' expectations and perceptions lead to impulsive online purchases and ultimately to an understanding of consumer satisfaction.

Keywords: Cross-border shopping, Cognitive, Impulse buying, Customer satisfaction.

Copyright @ 2020: This is an open-access article distributed under the terms of the Creative Commons Attribution license which permits unrestricted use, distribution, and reproduction in any medium for non-commercial use (NonCommercial, or CC-BY-NC) provided the original author and source are credited.

\section{INTRODUCTION}

The mode of cross-border e-commerce. According to different trading objects, we can divide cross-border e-commerce into $\mathrm{B} 2 \mathrm{~B}, \mathrm{~B} 2 \mathrm{C}$ and $\mathrm{C} 2 \mathrm{C}$. This study is mainly applied to the $\mathrm{B} 2 \mathrm{C}$ model. We operate and investigate the overall cross-border e-commerce business model based on the cross-border model. The covid-19 caused a global panic, with major consumers unable to buy items such as masks and alcohol. Through cross-border e-commerce platforms, consumers can choose amazon, taobao, jd.com or overseas purchasing agents to buy medical products such as masks and alcohol.In this series of shopping process, consumer satisfaction is very important. Mainly because this outbreak presents a sudden situation, whether consumers will be anxious to get masks, hand-washing alcohol and other related products. On the other hand, affected by the epidemic, consumers as a whole are more willing to let sellers observe the satisfaction of consumers when buying related medical products.
Park [1] proposed that hedonism would lead to impulsive buying. But this outbreak can turn into consumer panic and impulse buying. On the other hand, consumers' perceived ease of use will also lead to consumers' impulse purchase. Consumers' impulse buying is mainly influenced by some external environment, which leads to the urgent need to buy such medical products. Dowling [2], Srinivasan and Ratchford [3], mentioned the concept of consumer expected utility. So they think that consumers are going to be influenced by some outside information and that's going to have a cognitive impact. Therefore, consumers' perception and cognition will also determine whether to purchase relevant medical products on the online platform.

\section{LITERATURE REVIEW}

Cross-border shopping is mainly for consumers to enjoy the pleasure of goods that cannot be bought locally. For example, many overseas commodities, including baby food, milk powder, 
Li-Wei Lin et al; Saudi J Bus Manag Stud, March., 2020; 5(3): 196-199

cosmetics and other commodities, are purchased through cross-border means, which is a very important concept for consumers. In the case of the covid-19 outbreak, many consumers were unable to buy face masks or hand-washing alcohol in affected areas such as China, Taiwan, Hong Kong, Japan and South Korea. Consumers' satisfaction is mainly analyzed and explained from the aspects of tangible and reliability, which can mainly affect consumers' satisfaction with products. We take e-commerce platform as an example, many stores will discuss and discuss customer satisfaction, including good service quality can bring customer satisfaction. Okumus and Asil [4] mentioned that visible services through regression methods have a positive correlation with passengers. Chinomona \& Sandada [5] consumers' purchase intention generates their main interest in products and services. Consumer satisfaction is one of the important factors to be discussed in the process of online shopping. Consumer satisfaction mainly comes from consumers' satisfaction before and after shopping. Cross-border shopping is one of the key factors for consumer satisfaction. Fang et al., [6]; Zboja \& Voorhees [7], mentioned that trust is the source of consumer satisfaction, and how to obtain the trust relationship of consumers becomes a key factor. Ganesan [8] presented the first message that retailers should deal mainly with customer complaints. Our research mainly combines cross-border market concepts to guide, including consumers' buying behavior and attitude and related concepts of consumers' buying and cognition.

Shopping is mainly because consumers will get hedonism when buying, such a process for consumers is a shopping motivation. Seo and Lee [9] mentioned that shopping behavior is not only the hedonism of consumers, but also the overall shopping experience environment provided by sellers. Arnold and Reynolds [10] proposed that the consumerist culture in the United
States is consistent with the demand for consumption. We can understand that in the process of cross-border shopping, consumers mainly want to get a sense of enjoyment and shopping. But this global outbreak of covid-19 is not hedonism, again defying conventional wisdom. Evans, Lane and O "Grady [11] proposed the concept that cross-border shopping could enable consumers to buy favorable prices and good services.

Jones et al., [12] proposed that impulse buying would lead to the improvement of business performance. We can see from this outbreak that many consumers buy masks, hand-washing alcohol and other products in large quantities because of the expectation of panic. Chen and Wang [13] proposed that impulse buying would lead to the loss of self-regulation ability. Therefore, sometimes consumers' impulsive purchase will cause the imbalance between reperception and cognition, which will be affected by some external environmental factors.

\section{RESEARCH DESIGN}

The purpose of this study was to develop a structural model and test it to determine the impact of ecommerce platform cross-border shopping, impulse buying, and consumer perception on consumer satisfaction.

Through the questionnaire survey method, we designed the following three hypotheses. The hypothesis diagram is as follows.

H1: cross-border shopping has a positive correlation with consumer satisfaction

$\mathrm{H} 2$ : impulse buying has a positive correlation with consumer satisfaction

H3: consumer cognition has a positive correlation with consumer satisfaction

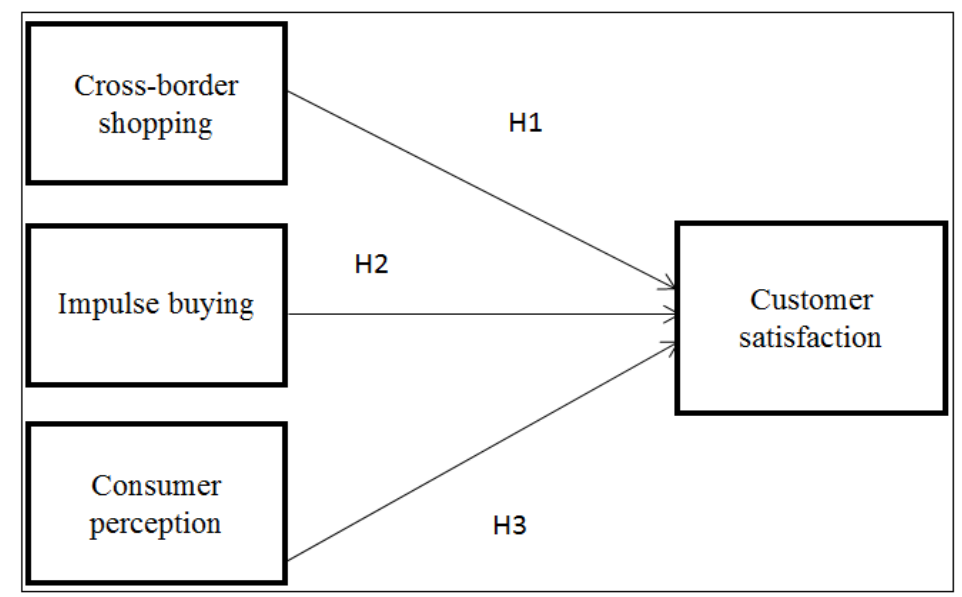

Fig-1: Study the design architecture diagram

Aiken, West, \& Reno [14] mentioned that in the case of potential multicollinearity of structural equation models, independent variables and regulators are centered on the mean. We design the impact of cross-border shopping, impulse buying and consumer perception on customer satisfaction. Most samples of 
Li-Wei Lin et al; Saudi J Bus Manag Stud, March., 2020; 5(3): 196-199

the study were collected through online surveys. Because our research aims to investigate the satisfaction of its consumers in online shopping survey. Consumers' online satisfaction is a very important factor for crossborder e-commerce. Consumers' good experience and purchase experience will further lead to consumers' purchase intention.

\section{EMPIRICAL ANALYSIS}

Questionnaires were used in this study. The survey was conducted among consumers shopping on ecommerce platforms. The questionnaire is divided into two parts. (1) In determining demographic characteristics. (2) Determine the impact of crossborder shopping, impulse buying and consumer perception on customer satisfaction. The questionnaire was based on a seven-point likert scale (1: "strongly disagree", 2: "disagree", 3: "somewhat disagree", 4: "average", 5: "somewhat agree", 6: "agree" and 7: "strongly agree"), and asked each participant to give appropriate answers to their situation. We use the structural equation model approach to understand the relationship between overall measurement and structure. We investigated a sample size of 206 people to see whether the outbreak would affect consumers' cross-border shopping online.

Table-1: Questionnaire factor form

\begin{tabular}{|l|l|l|l|}
\hline & Options & Man-Time & Percentage \\
\hline \multirow{4}{*}{ customer satisfaction } & fast delivery & 23 & $11 \%$ \\
\cline { 2 - 4 } & service attitude & 31 & $15 \%$ \\
\cline { 2 - 4 } & platform operation process is clear & 152 & $73.7 \%$ \\
\hline \multirow{3}{*}{$\begin{array}{l}\text { factors influencing cross-border } \\
\text { shopping }\end{array}$} & method of payment & 143 & $69 \%$ \\
\cline { 2 - 4 } & price & 32 & $15.5 \%$ \\
\cline { 2 - 4 } & Product origin & 31 & $15 \%$ \\
\hline \multirow{4}{*}{ impulse buying } & external environment & 42 & $20 \%$ \\
\cline { 2 - 3 } & information sharing & 65 & $31.5 \%$ \\
\cline { 2 - 3 } & word of mouth to spread & 99 & $48 \%$ \\
\hline \multirow{3}{*}{ consumer perception } & consumer belief & 48 & $23.3 \%$ \\
\cline { 2 - 3 } & trust & 56 & $27 \%$ \\
\cline { 2 - 3 } & perception & 102 & $49.5 \%$ \\
\hline
\end{tabular}

\section{DISCUSSION AND CONCLUSION}

The main purpose of this study is to investigate consumers' panic about masks, alcohol and other medical products caused by covid-19. Factors such as cross-border shopping, impulse buying and cognition of consumers will affect the impact of consumer satisfaction. Through cross-border shopping, we can know how consumers will use cross-border shopping, so we take into account all the purchasing behaviors of consumers. From the perspective of management application, cross-border shopping is influenced by external environment to lead to consumers' shopping situation, and we can finally see the relationship between consumers' satisfaction.In the process of research, we were mainly influenced by the national sources of questionnaire filling by global consumers. In the process of sorting out, there would be no response bias in questionnaire filling, and researchers need to take this non-response bias into consideration in the future. Mottus, Lamas, and Pajusalu [15]; Mazumder et al., [16] proposed that consumers are mainly affected by the whole shopping experience, including the overall visual, mechanism and other related influences.

\section{ACKNOWLEDGEMENT}

This research was supported by the NSF Grant Nos. 61972337 and 61502414

\section{REFERENCES}

1. Park, E. J., Kim, E. Y., Funches, V. M., \& Foxx, W. (2012). Apparel product attributes, web browsing, and e-impulse buying on shopping websites. Journal of Business Research, 65(11):1583-89.

2. Dowling, G. R. (2004). Corporate reputations: Should you compete on yours? California Management Review, 46(3):19-36.

3. Srinivasan, N., \& Ratchford, B. T. (1991). An empirical test of a model of external search for automobiles. Journal of Consumer Research, 18(2):233-242.

4. Okumuş, A., \& Asil, H. (2007). Hizmet Kalitesi Algılamasının Havayolu Yolcularının Genel Memnuniyet Düzeylerine Olan Etkisinin İncelenmesi. İstanbul Üniversitesi Işsletme Fakültesi Dergisi, 36(2):7-29.

5. Chinomona, R., \& Sandada, M. (2013). The influence of market-related mobile activities on the acceptance of mobile marketing and consumer intention to purchase products promoted by SMS in South Africa. Journal of Applied Business Research, 29(6):1897-1908. Retrieved from http://ezproxy.snhu.edu/login?url=http://search.pro quest.com/docview/147 3895722? accountid=3783

6. Fang, Y., Qureshi, I., Sun, H., McCole, P., Ramsey, E., \& Lim, K. (2014). Trust, satisfaction, and online repurchase intention: The moderating role of perceived effectiveness of E-Commerce 
institutional mechanisms. Management Information Systems Quarterly, 38(2):407-427.

7. Zboja, J. J., \& Voorhees, C. M. (2006). The impact of brand trust and satisfaction on retailer repurchase intentions. Journal of Services Marketing, 20(6):381-390.

8. Ganesan, S. (1994). Determinants of long-term orientation in buyer-seller relationships. Journal of Marketing, 58(2):1-19.

9. Seo, S., \& Lee, Y. (2008) Shopping values of clothing retailers perceived by consumers of different social class. Journal of Retailing and Consumer Services, 15:491-499.

10. Arnold, M. J., \& Reynolds, K. E. (2003). Hedonic shopping motivations. Journal of Retailing, 79:77-95.

11. Evans, Wendy, Henry Lane and Shawna O Orady (1992), Border Crossings: Doing Business in the US. Scarborough, Ontario: Prentice Hall Canada.

12. Jones, M. A., Reynolds, E., Weun, S., \& Beatty, S.
E. (2003). The product-specific nature of impulse buying tendency. Journal of Business Research, 56(7):505-511.

13. Chen, T., \& Lee, M. C. (2015). Personality antecedents of online buying impulsiveness. Journal of Economics, Business and Management, 3(4):425-429.

14. Aiken, L. S., West, S. G., \& Reno, R. R. (1991). Multiple regression: Testing and interpreting interactions. Newbury Park, CA: SAGE.

15. Mottus, M., Lamas, D., Pajusalu, M., \& Torres, R. (2013). The evaluation of interface aesthetics. In Proceedings of the international conference on multimedia, interaction, design and innovation, ACM, Warsaw, Poland.

16. Mazumdar, S., Petrelli, D., Elbedweihy, K., Lanfranchi, V., \& Ciravegna, F. (2015). Affective graphs: The visual appeal of linked data. Semantic Web, 6(3):277-312. 